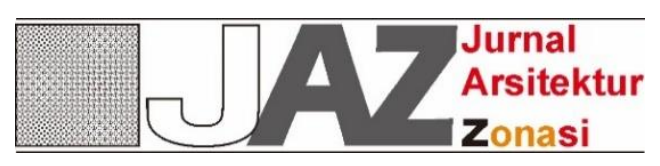

http://ejournal.upi.edu/index.php/jaz - e-mail: jurnal.zonasi@gmail.com dan jurnal_zonasi@upi.edu doi.org/10.17509/jaz.v3i2.25893

\title{
KONFIGURASI RUANG BERDASARKAN KUALITAS KONEKTIVITAS RUANGAN DALAM PERANCANGAN KANTOR: SPACE SYNTAX ANALYSIS
}

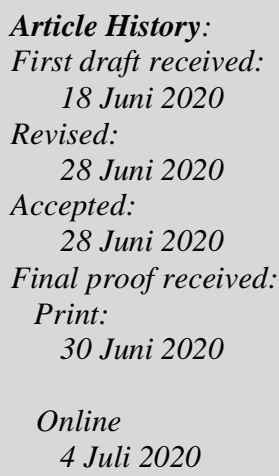

Jurnal Arsitektur ZONASI is indexed and listed in several databases:

SINTA 4 (Arjuna)

GARUDA (Garda Rujukan Digital) Google Scholar

Dimensions

oneSearch

BASE

Member:
Crossref
RJI
APTARI
FJA (Forum Jurna Arsitektur)
IAI
AJPKM

\author{
Asep Yudi Permana ${ }^{1}$ \\ Aathira Farah Salsabilla Permana ${ }^{2}$ \\ Deka Andriyana ${ }^{3}$ \\ ${ }^{1}$ Universitas Pendidikan Indonesia, Bandung, Indonesia \\ Jln.Dr. Setiabudhi no.207-229 Bandung, 40154 \\ 2 Institut Teknologi Nasional, Bandung, Indonesia \\ Jln. PHH. Mustofa No. 23 Bandung, 40124 \\ ${ }^{3}$ Universitas Kebangsaan Republik Indonesia, Bandung, Indonesia \\ Jln Terusan Halimun no. 37 Bandung \\ Email: yudi.permana@upi.edu \\ aathira.sape@gmail.com \\ andryanadesign27@gmail.com
}

Abstract: The complexity that occurs in an office is determined by the diversity and intensity of user activity. Connectivity system becomes an important factor to accommodate activities in their work, especially connectivity from private work areas to shared work areas and public services. This study aims to analyze the activities of employees and their connectivity, including the flow of circulation in the office of PT. Haleyora Powerindo after undergoing a re-design and evaluation for 5 months after office operations. Space Syntax Analysis is done to see how changes in behavior and connectivity occur. Data is collected by direct observation and review of secondary sources related to the development and changes that occur in the office. It was concluded that connectivity and permeability in the design of an office require a comfortable circulation area with a range that is not too long between nodes as an observation room with a path as a circulation area.

Keywords: Behavior, Space, conectivity, permeability, office.

\begin{abstract}
Abstrak: Kompleksitas yang terjadi di dalam sebuah perkantoran ditentukan oleh keragaman dan intensitas aktivitas penggunanya. System konektivitas menjadi faktor penting untuk mengakomodasi kegiatan dalam pekerjaannya, terutama konektivitas dari area kerja pribadi ke area kerja Bersama dan layanan publik. Penelitian ini berutujuan untuk menganalisis aktivitas pegawai dan konektivitasnya termasuk alur sirkulasi di kantor PT. Haleyora Powerindo setelah mengalami re-desain dan dilakukan evaluasi selama 5 bulan pasca operasional kantor. Space Syntax Analysis dilakukan untuk melihat bagaimana perubahan perilaku dan konektivitas yang terjadi. Data dikumpulkan dengan observasi langsung dan review sumber sekunder yang terkait dengan pengembangan dan perubahan yang terjadi di kantor tersebut. Disimpulkan bahwa konektivitas dan permeabilitas pada rancangan sebuah kantor memerlukan area sirkulasi yang nyaman dengan jangkau yang tidak terlalu panjang antara node sebagai ruang pengamatan dengan path sebagai area sirkulasi.
\end{abstract}

Kata Kunci: Perilaku, Ruang, Konektivitas, Permiabilitas, Kantor

\section{Pendahuluan}

Kantor sebagai satu ruang yang berfungsi sebagai tempat untuk bekerja para pegawai dengan baik. Untuk itu perancangan suasana ruang kantor sangat dibutuhkan agar tercipta suasana kantor yang nyaman dan aman. Proses kegiatan perancangan merupakan suatu proses implementasi konsep ke dalam rancangan dengan 
mempertimbangkan besaran ruang, tata letak perabotan, sirkulasi pergerakan manusia, dan penerapan material pembentuk ruangnya.

Perancangan ruang kantor merupakan suatu perencanaan dan perancangan yang berfungsi untuk memecahkan permasalahan yang ada di dalam suatu kantor dengan memperhatikan unsur-unsur pembentuk ruang agar tercipta suatu ruang kantor yang representatif, nyaman, aman bagi pegawainya. Oleh karena itu, dalam perancangan interior ruang faktor utama yang harus diperhatikan adalah aktivitas pegawai.

Untuk kenyamanan dan keamanan bekerja pegawai, selain besaran ruang yang sesuai dan tata letak perabotan yang perlu diperhatikan adalah sirkulasi pergerakan manusia dan penerapan material dalam ruang. Oleh karena itu PT. Haleyora Powerindo melalui beberapa anak perusahaan dalam menjalankan roda layanan kepada publik, juga tidak lepas bagaimana perusahaan mengakomodir kebutuhan para pegawai dalam kenyamanan dan keamanan dalam bekerja. Perusahaan harus bisa memberilakn layanan yang cepat dan memuaskan kepada pegawai, karena pegawai merupakan kekuatan dalam menjalankan roda perusahaan. Dukungan kualitas ruang dan fasilitas ruang merupakan hal pokok dalam rangka perusahaan memberikan layanan kepada pegawainya, sehingga akan berdampak kepada produktivitas kerja pegawai.

Ruang kerja sebagai tempat kerja menuntut penataan yang memberikan kenyamanan kerja pegawai. Littlefield dan Peterson, (1956) menyatakan bahwa perancangan interior kantor merupakan satu susunan peralatan sesuai dengan besaran ruang dan fungsinya. Menurut Gie, (2000) di dalam kegiatan perancangan interior, kegiatannya dimulai dari menentukan kebutuhan, fungsi ruang berdasarkan kepada faktor-faktor yang mempengaruhi pelaksaanaan sampai dengan menghitung anggaran biayanya. Lebih lanjut Gie, (2000) menjelaskan dalam perancangan ruang perlu mempertimbangkan standarisasi ruang mulai dari pengguna, jarak, alur kerja(Adien dan Setiadi, 2017)(Armiati, 2015)(Williamson, 2015).

Penataan ruang (Permana, Akbardin, F.A., Permana, dan Nurrahman, 2020)merupakan hal yang penting dan tidak terpisahkan dengan suasana ruang secara fisik disekitarnya, karena kondisi ini sangat mempengaruhi kinerja pegawai (Ridwan, Niswaty, dan Darwis, 2018). Dengan demikian tata ruang kerja merupakan hal penting yang harus diperhatian dalam mendukung efektivitas dan produktivitas pegawai. Peningkatan produktivitas kerja melalui pemberdayaan SDM yang harus menjadi komitmen seluru manajemen.

Penelitian tentang konfigurasi ruang sangat penting dilakukan dalam rangka mencari model konfigurasi ruang yang tepat dalam sebuah perancangan interior sebuah kantor. Berdasarkan hasil kajian awal sudah ada beberapa penelitian yang terkait dengan kenyamanan ruang, penataan ruang, dan pengaruh kenyamanan ruang terhadap produktivitas, maupun profesionalisme pegawai, akan tetapi terkait tentang penelitian konfigurasi ruang berdasarkan kualitas konectivitas ruangan masikn belum banyak diteliti. Hal inilah yang melatar belakangi pelaksanaan penelitian ini. Diharapkan hasil penelitian ini menjadi rujukan dalam pengembangan desain interior sebuah kantor.

\section{Kajian Teori}

\subsection{Analisis Konfigurasi Ruang}

Metode analisis konfigurasi ruang menggunaan space syntax analytical, analisis ini digunakan untuk menentukan bagaimana tata letak berfungsi, menunjukkan apa yang dapat dilihat pegawai sebagai pengguna dari berbagai titik di dalam ruangan dan tingkat kemudahan dan kesulitan pencapaian ruangan. Analisis space syntax digunakan untuk menghasilkan kombinasi dari grafik visibilitas, polygon visibilitas, konektivitas ruang.

Hillier dan Hanson, (1984) menjelaskan bahwa space syntax analisys digunakan untuk menganalisis hubungan spasial antara ruang yang berdekatan dan mengidentifikasi konektivitas ruang secara langsung maupun tidak langsung (McLane dan Pable, 2020)(Permana dan Wijaya, 2019). Main entrance ebagai titik awal masuk ke dalam ruangan, semua ruangan yang terhubung ke main entrance berjarak satu langkah sintaksis dan ditarik satu tingkat ke atas (Adiyanto, 2016)(Hillier, 2007). Semakin banyak level dalam grafik, semakin besar ruang yang tersedia bagi pengguna. Hubungan spasial digambarkan dalam grafik hubungan ruang dengan membentuk struktur jaringan ruang dengan sirkulasi(Warada dan Mutiara, 2013)(Hanson, 1998).

Grafik sebagai pohon jaringan mewakili hubungan ruang di mana pengguna harus melewati ruang demi ruang untuk mencapai ruang terjauh. Konfigurasi (Darjosanjoto, 2006) pohon jaringan hubungan ruang menggambarkan tata letak tipe koridor dengan pergerakan yang dikontrol ketan melalui ruang. Organisasi ruang sebagai hierarki yang membutuhkan kontrok ketat atas tatanan sosial. Hal ini sejalan dengan pendapat Hillier dan Hanson, (1984) konfigurasi merupakan sebuah hubungan di mana terdapat obyek-obyek yang saling bergantung satu sama lain dalam suatu struktur (Adiyanto, 2016)(Permana, Soetomo, Hardiman, dan Buchori, 2013)(Darjosanjoto, 2006)(Hillier, Penn, Hanson, Grajewski, dan Xu, 1993)(Hillier, Burdett, Peponis, dan Penn, 1987). 
Permeabilitas dan aksesibilitas sebagai pola jaringan yang menjadi komponen penting dalam perancangan karena mempengaruhi aspek kualitas ruang (Siregar, 2014). Permeabilitas sebagai parameter untuk mengukur sejauh mana konfigurasi ruang dalam menyediakan pilihan dalam menempuh perjalanan dan aksesibilitas. Parameter yang diukur dalam permiabilitas sebagai hasil dari interaksi antara individu dengan sistem ruang (Siregar, 2014).

Pola dan intensitas pergerakan pengguna dipengaruhi oleh pergerakannya dalam ruang. Hillier, (2007) membagi ke dalam 4 dimensi, yaitu:

\section{(1) Topological distance}

Menurut Hillier et al., (1987) topological distance sebagai konsep jarak dengan menghitung kedalamam (depth) berdasarkan ukuran langkah (step). Darjosanjoto, (2006) menjelaskan bangaimana cara menghitung dan mengukur ukuran langkah (step), antara lain: 1 step depth berarti jarak antara dua buah ruang yang terhubung secara langsung, 2 step depth berarti jarak antara ruang A dan B dimana harus melewati 1 buah ruang antara. Pada gambar 1 , jarak antara $\mathrm{a}-\mathrm{b}, \mathrm{b}-\mathrm{c}$ dan sebaliknya masing-masing senilai 1 step depth sementara jarak a - $\mathrm{c}$ dan sebaliknya senilai 2 step depth sebab harus melewati ruang $\mathrm{b}$ (1 step depth +1 step depth = 2 steph depth) (Permana dan Wijaya, 2019)(Hadiansyah, 2017)(Siregar, 2014). Kosenp dasar step depth dapat dilihat pada gambar 1.

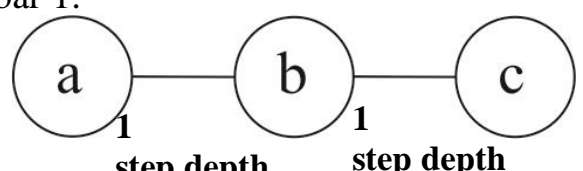

step depth step depth

Gambar 1. Konsep Step depth

Sumber: Siregar, (2014)

\section{(2) Connectivity}

Connectivity (Hillier et al., 1987)sebagai dimensi untuk mengukur dengan cara menghitung jumlah ruang yang secara langsung terhubung dengan ruang lainnya dalam suatu konfigurasi ruang(Hillier et al., 1993). Jumlah ruang yang terhubung dihitung dengan mempergunakan konsep jarak (depth), artinya jika suatu ruang dikatakan terhubung secara langsung apabila hanya memiliki jarak sebesar 1 step depth. Penggunaan pengurkuran connectivity ini ditujukan untuk menemukan tingkat interaksi setiap ruang terhadap ruangruang yang berada didekatnya. Darjosanjoto, (2006) menjelaskan bahwa nilai connectivity digunakan untukmengukut tingkat intelligibility dengan cara mencari hubungan antara nilai connectivity dengan nilai integrity (Permana dan Wijaya, 2019)(Hutama, 2016)(Siregar, 2014). Konsep dasar connectivity dapat dilihat pada gambar 2.

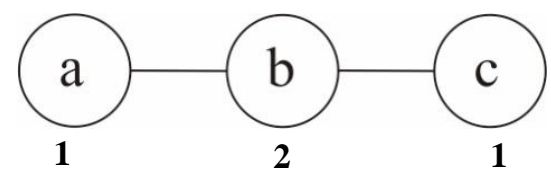

Gambar 2. Nilai Connectivity dari konfigurasi ruang ilustrasi 1

Sumber: Siregar, (2014)

Berdasarkan gambar 2 artinya ruang a dan ruang c mempunyai nilai connectivity sebesar 1, karena hanya terhubung pada 1 ruang, sedangkan ruang b mempunyai nilai connectivity sebesar 2 karena terhubung ke 2 ruangan.

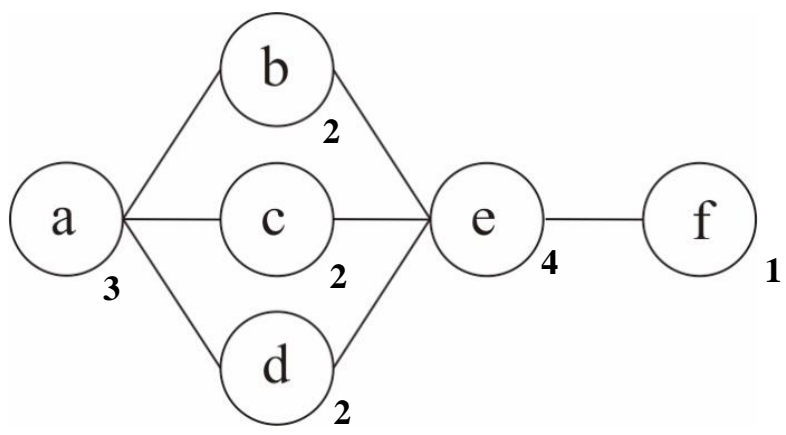

Gambar 3. Nilai Connectivity dari konfigurasi ruang ilustrasi 2 Sumber: Siregar, (2014) 
Berdasarkan gambar 3 Ruang a mempunyai nilai connectivity sebesar 3 (terhubung ke 3 ruangan b,c, dan d), sedangkan Ruang b, c, dan d mempunyai nilai connectivity sebesar 2 (terhubung ke 2 ruangan). Ruang e mempunyai nilai connectivity sebesar 4, dan Ruang f mempunyai nilai connectivity sebesar 1.

\section{(3) Integrity}

Integrity (Hillier, 2007) digunakan untuk mengukur posisi relatif dari masing-masing ruang terhadap ruangruang lainnya dalam satu konfigurasi ruang. Perhitungan nilai integrity tidak hanya melibatkan ruang-ruang yang secara langsung terkoneksi, tetapi juga ruang-ruang lainnya yang tidak langsung terkoneksi dengan ruang yang diobservasi/diamati (Permana dan Wijaya, 2019)(Hillier, 2007)(Hillier dan Hanson, 1984).

Integrity ini sebagai salah satu pengukuran yang paling penting dalam space syntax, karena melalui pengukuran integrity analisis terhadap konfigurasi ruang sebagai sebuah sistem dapat dilakukan. Integrity sebagai posisi relatif sebuah ruang dihitung dengan mempergunakan metode step depth(Permana dan Wijaya, 2019)(Hillier dan Hanson, 1984)(Siregar, 2014). Ruang dengan nilai step depth tinggi dianggap memiliki interaksi yang tinggi secara relatif terhadap ruang-ruang lainnya, dalam arti ruang tersebut terkoneksi secara baik ke ruang yang diobservasi. Semakin banyak ruang yang terkoneksi secara langsung dengan ruang amatan/observasi, maka semakin tinggi pula nilai integrity ruang tersebut atau sebaliknya (Hillier, 2007)(Siregar, 2014). Konsep dasar nilai integrity dapat dilihat pada gambar 4.

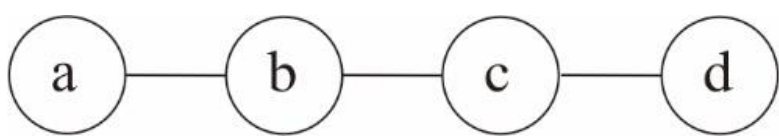

Gambar 4. Ruang pengamatan dengan integrity rendah Sumber: Siregar, (2014)

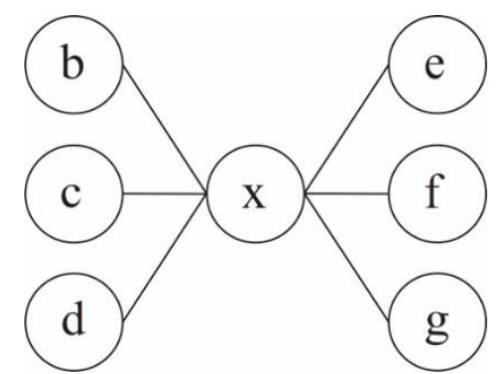

Gambar 5. Ruang pengamatan dengan integrity tinggi

Sumber: Siregar, (2014)

Berdasarkan gambar, ruang a dan ruang $d$ sebagai ruang yang pengamatan mempunyai nilai integrity rendah karena memiliki lebih banyak ruang antara (ruang $\mathrm{b}$ dan ruang $\mathrm{c}$ ). sedangkan pada gambar, ruang $\mathrm{x}$ mempunyai nilai integrity yang tinggi karena terhubung secara langsung ke banyak ruang di sekitarnya.

\section{(4) Intelligibility}

Intelligibility (Hillier dan Hanson, 1984) merupakan tahap pengukuran tertinggi dalam analisis space syntax. Nilai ini menunjukkan adanya korelasi antara connectivity dengan integrity. Intelligibility sebagai pengukuran struktur dari suatu konfigurasi ruang, di mana hasil pengukuran intelligibility akan menjadi alat pada sistem sementara hasil pengukuran connectivity dan integrity akan menjadi alat pada masing-masing ruang (Siregar, 2014).

Nilai Intelligibility sebagai hipotesis menunjukkan bahwa konektivitas ruang mencerminkan adanya kemudahan dalam pencapaian ke ruang-ruang lainnya(Hadiansyah, 2017). Sebaliknya nilai intelligibity yang rendah mencerminkan bahwa struktur ruang tidak dapat dipahami dari keberadaan ruang secara parsial (Siregar, 2014)(Hillier et al., 1987). Nilai intelligibility ini dihitung dengan mempergunakan analisis korelasi dalam dua cara, yaitu Koefisien korelasi produk momen Pearson (r) dan Regresi sederhana.

$$
\begin{aligned}
& r_{x y}=\frac{\sum x y}{\sqrt{\sum x^{2} y^{2}}} \\
& \text { rxy }=\text { korelasi antara } \mathrm{x} \text { dan } \mathrm{y} \\
& x=\left(x_{i}-\bar{x}\right) \\
& y=\left(y_{i}-\bar{y}\right)
\end{aligned}
$$




\section{Metode Penelitian}

\subsection{Lokasi Penelitian}

Penelitian dilakukan di PT. Haleyora Powerindo Jln. PHH. Mustofa no 45 Bandung pasca re-desain tata ruang/interior Gedung kantor pada tahun 2018. PT. Haleyora Powerindo merupakan salah satu perusahaan dalam penyediaan dan pengelolaan Sumber Daya Manusia yang professional(Hadiansyah, 2017) di bidang operasi dan pemeliharaan transmisi dan distribusi tenaga listrik dan bidang pendukung lainnya. Visi dari perusahaan adalah menjadikan perusahaan terkemuka penyedia layanan Operasi dan Pemeliharaan Transmisi dan Distribusi bidang ketenagalistrikan yang memberikan layanan dengan standar mutu tinggi dan menerapkan kesempurnaan keselamatan, kesehatan dan lingkungan kerja, kesempurnaan operasional dan penyempurnaan berkesinambungan. Lokasi penelitian ini dapat dilihat seperti pada gambar 6.

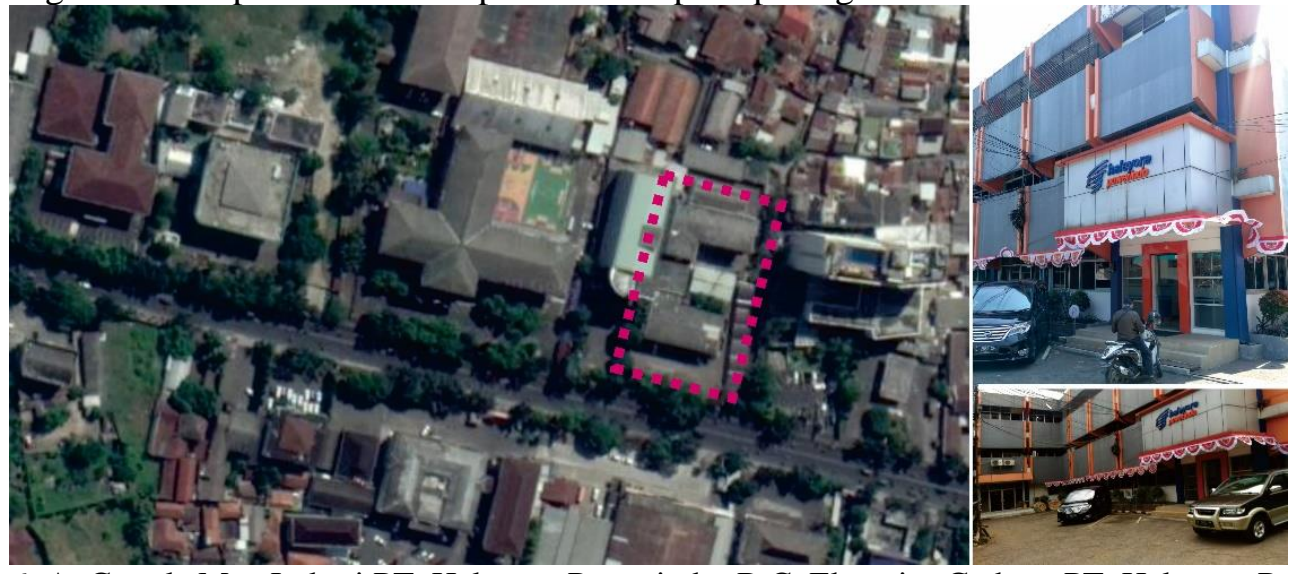

Gambar 6. A. Google Map Lokasi PT. Haleyora Powerindo; B,C. Eksterior Gedung PT. Haleyora Powerindo Sumber: Google map 2019 dan Dokumen PT. Athila Consultant,2019

Bangunan PT. Haleyora Powerindo terdiri dari 3 lantai, seperti terlihat pada gambar 7, 8, dan 9.

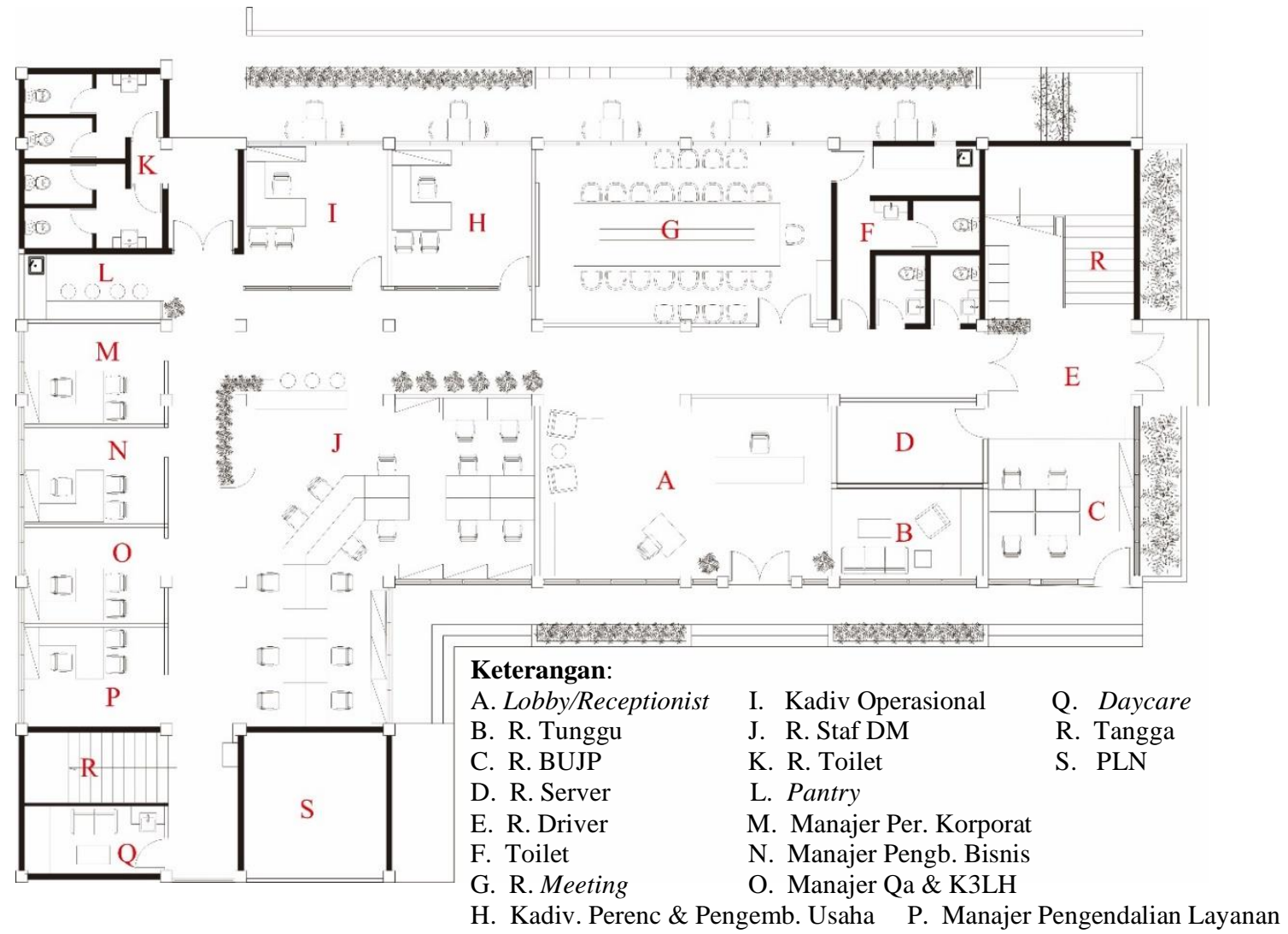

Gambar 7. Denah Lantai Dasar

Sumber; PT. Athila Consultant, 2019 


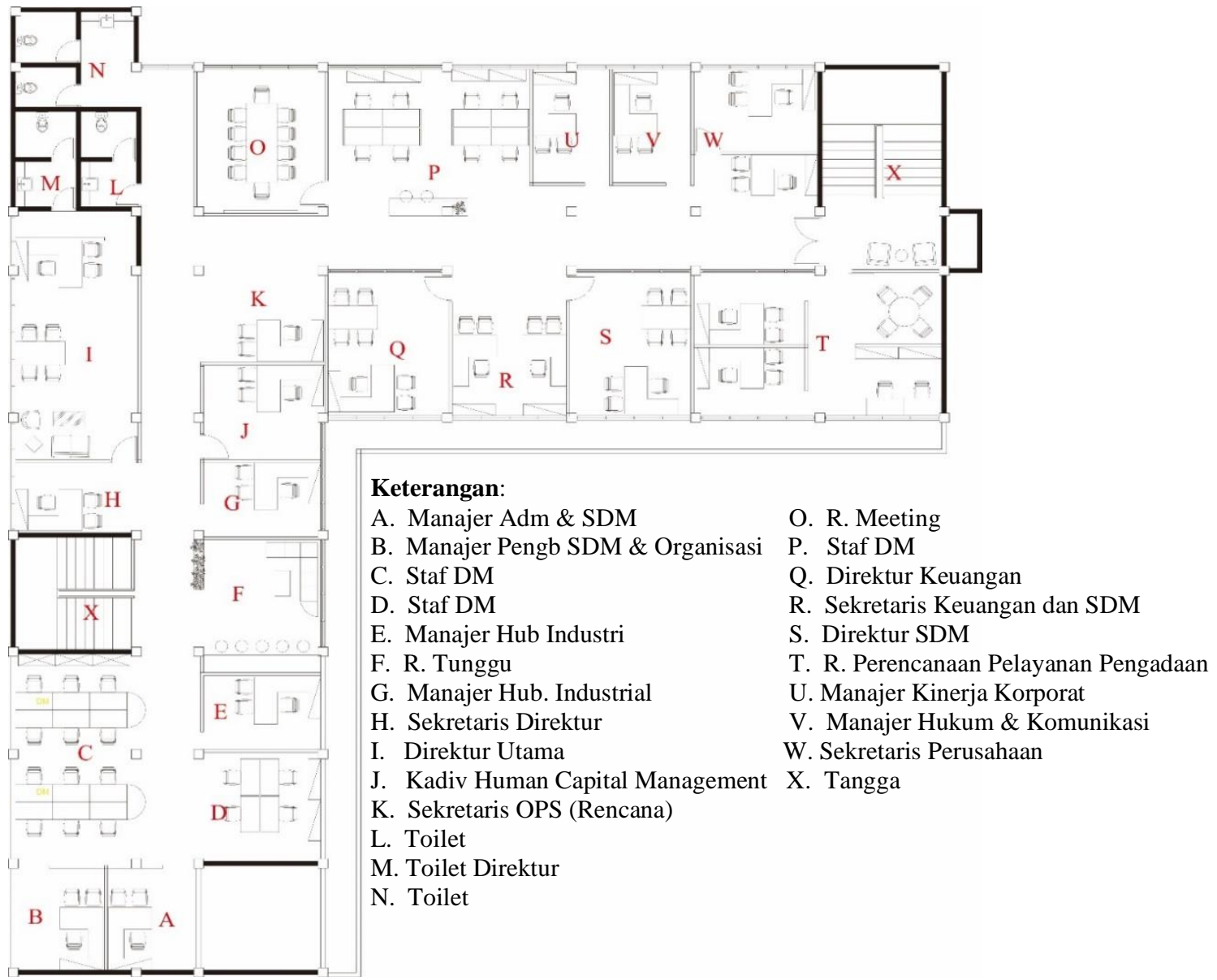

Gambar 8. Denah Lantai 2

Sumber; PT. Athila Consultant, 2019

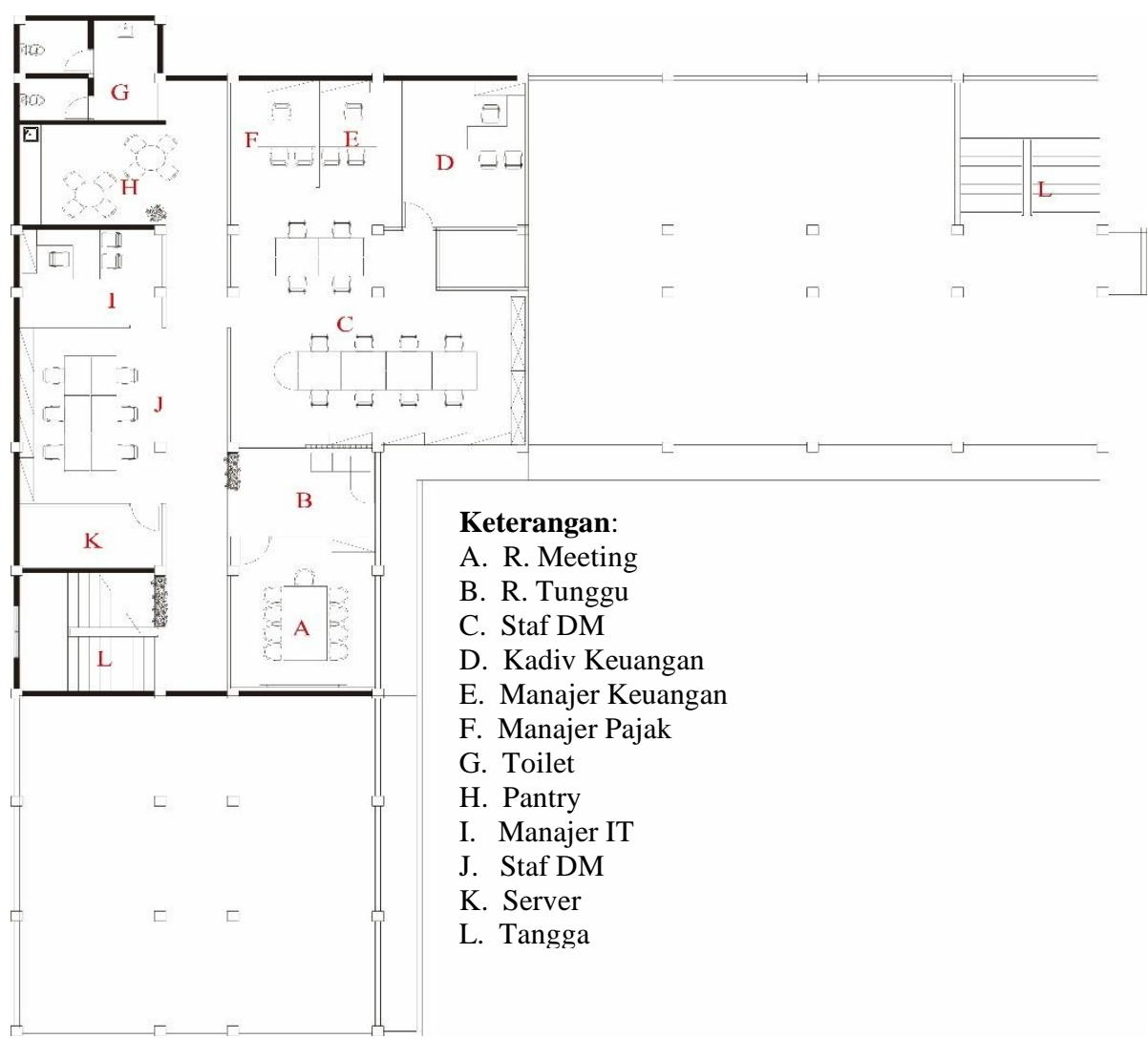

Gambar 9. Denah Lantai 3

Sumber; PT. Ahila Consultant, 2019 
Berdasarkan data denah re-desain interior ruang Lantai Dasar, Lanta Dua, dan Lantai Tiga dianalisis berdasarkan konfigurasi ruang-ruang yang ada dengan menggunakan space syntax analysis.

\subsection{Metode perhitungan Space Syntax Analysis}

Sebagai dasar dalam analisis ruang selain menggunakan bantuan program software deapthmapX v.0,70, juga didukungan beberapa perhitungan nilai integrity untuk setiap ruangnya, antara lain

a. Nilai total depth (TD)

Nilai TD ini dihitung melalui penjumlahan setiap step depth seluruh ruang menuju ruang pengamatan.

b. Nilai mean depth (MD)

$$
M D=\frac{T D}{L-1}
$$

Keterangan:

$$
\begin{array}{ll}
\mathrm{MD} & =\text { mean depth } \\
\mathrm{TD} & =\text { total depth } \\
\mathrm{L} & =\text { jumlah ruang dalam sistem }
\end{array}
$$

c. Nilai relative asymmetry (RA)

$$
R A=\frac{2(M D-1)}{L-2}
$$

Keterangan:

$$
\begin{array}{ll}
\mathrm{RA} & =\text { relative asymmetry } \\
\mathrm{MD} & =\text { mean depth } \\
\mathrm{L} & =\text { jumlah ruang dalam system }
\end{array}
$$

d. Nilai real relative asymmetry (RAA)

$$
R R A=\frac{R A}{G_{L}}
$$

Keterangan:

$$
\begin{array}{ll}
\mathrm{RAA} & =\text { real relative asymmetry } \\
\mathrm{RA} & =\text { relative asymmetry } \\
\mathrm{GL} & =\mathrm{RA} \text { terstandar }
\end{array}
$$

e. Nilai relative asymmetry terstandar

$$
G_{L}=2 \frac{L(L)^{1 / 2}-2 L+1}{(L-1)(L-2)}
$$

Keterangan:

$\mathrm{GL}=$ relative asymmetry (RA) terstandar

$\mathrm{L} \quad=$ jumlah ruang dalam system

sumber: Siregar, (2014)

Deskripsi dari perhitungan ini, jika suatu ruang memiliki nilai RRA rendah, maka ruang tersebut mempunyai nilai integrity yang tinggi dalam suatu konfigurasi ruang.

\section{Hasil dan Pembahasan}

Analisis tata ruang, data kegiatan individu dan sosial menunjukkan tiga kategori faktor yang mempengaruhi pegawai, yaitu, konfigurasi ruang, estetika, dan desain suasana ruang. Hasil penelitian ini terkait dengan aspek ruang dan konfigurasi ruang, fasilitas pendukung ruang, elemen pembentuk ruang. Analisis konfigurasi ruang ini dimulai dengan deskripsi hasil observasi untuk seluruh ruang pengamatan yang 
kemudian dilakukan analisis dengan model space syntax analysis untuk mendapatkan gambaran konfigurasi ruang terkait dengan topological distance, connctivity, integrity, dan intelligibility. Semua ruang-ruang yang ada dianalisis ke dalaman dan hubungan antar ruang satu dengan lainnya, ini ditujukan untuk mendapatkan nilai konektivitas dan integritas antar ruang.

\subsection{Desain Interior Kantor PT. Haleyora Powerindo}

Pada desain interior kantor PT. Haleyor Powerindo pengelompokan ruang berdasarkan struktur organisasi yang ada. Hal ini ditujukan untuk lebih mempermudah hubungan dalam sistem kerja antar unit. Pembatas ruang hanya digunakan sebagai pembeda zone kerja dengan tetap transparan, material yang digunakan partisi kaca dengan rangka alumunium dan pada bagian tertentu menggunakan sunblass untuk mendapatkan privasi terutama untuk ruang kerja manajer. Ilustrasi Tampak Depan gedung PT. Haleyora Powerindo dapat dilihat seperti pada gambar 10.

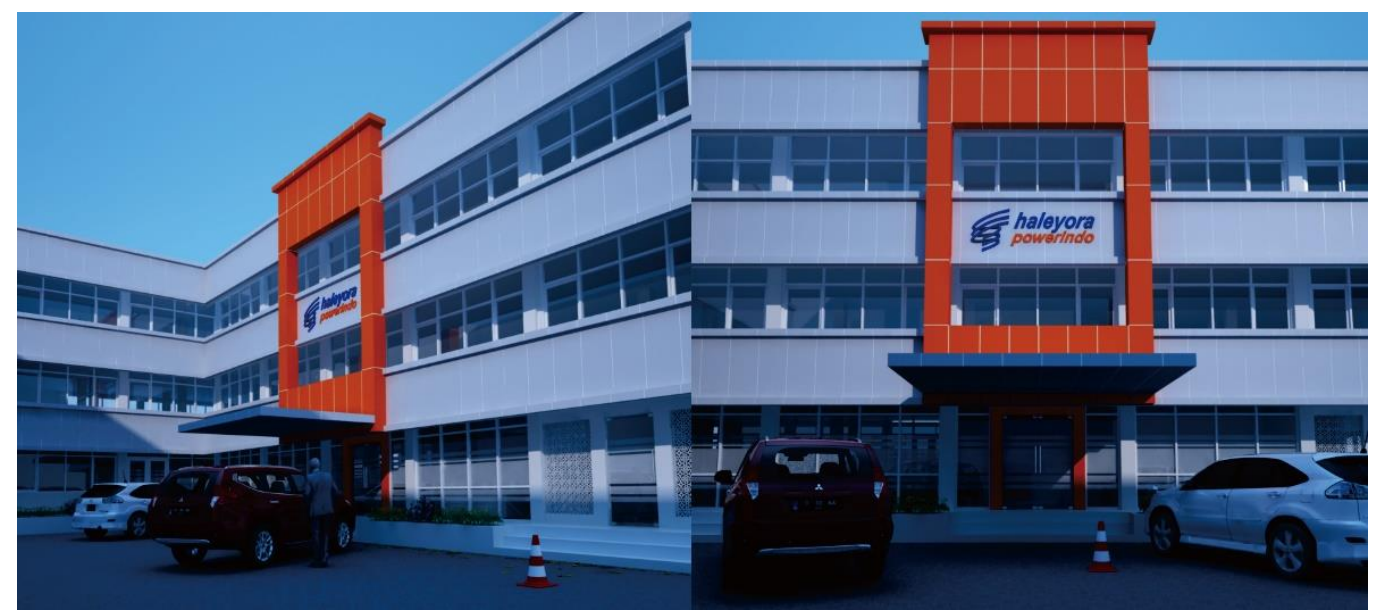

Gambar 10. (A,B) Perspektif Exterior Gedung PT. Haleyora Powerindo.

Sumber: Dokumen PT. Athila Consultant,2019

Berdasarkan hasil observasi untuk seluruh ruang, dapat digambarkan elemen pembentuk ruang dan fasilitas pendukung ruang (gambar 11 dan gambar 12), sebagai berikut:

a. Elemen Lantai

Material finishing lantai sebagai bagian dari perancangan interior menggunakan kombinasi dari beberapa material. Untuk area koridor digunakan lantai semen concret yang difinishing dengan epoxy floor warna biru langit yang dikombinasikan dengan spot ceramic polis.

Lantai ruang kerja menggunakan material parket tipe laminated. Penggunaan material parket ini memberikan kesan hangat, nyaman, dan santai. Motif parket memanjang dipilih dengan warna kayu jati sehingga ruangan tampak luas dan hangat. Pada area beberapa bagian ruang seperti ruang publik, pantry dan ruang makan digunakan material keramik/granit, ditujukan agar ruangan bersih, stlylish, dan memberikan kesan modern. Khusus area basah (seperti toilet) menggunakan keramik jenis unpolis.
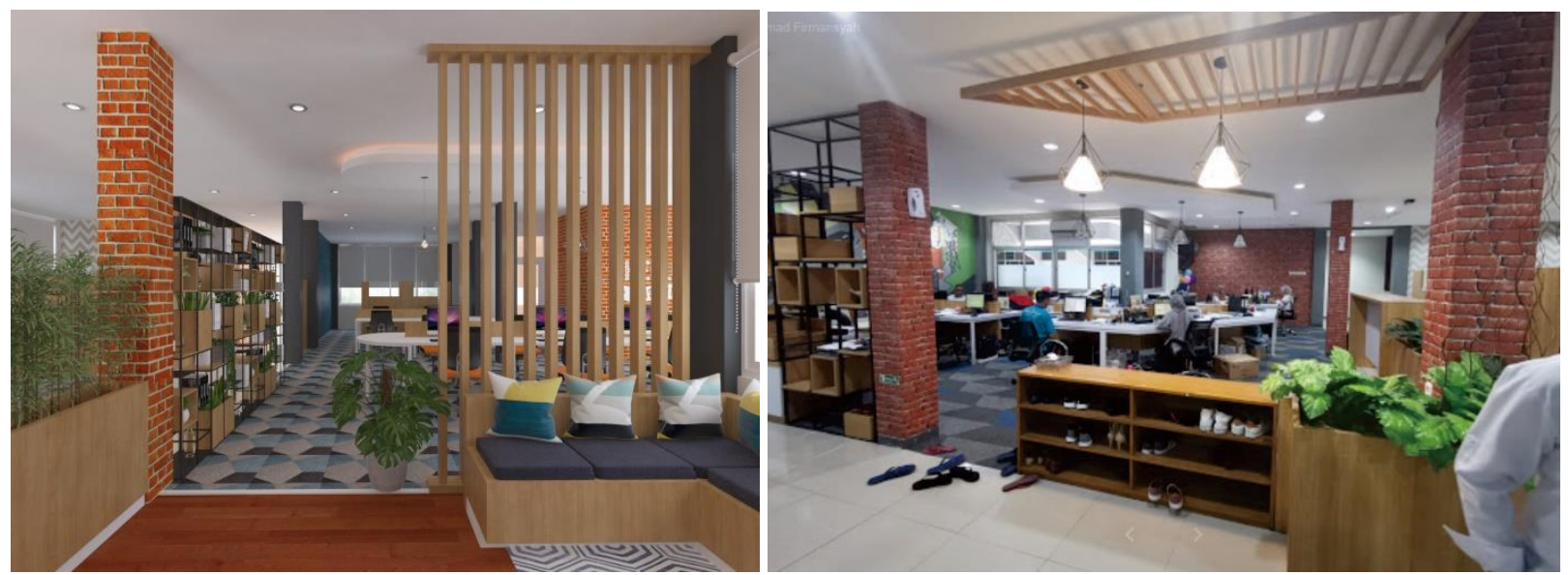

Gambar 11. (A.) Denah Existing; (B.) Pengelompokkan Zone sesuai fungsi ruang; dan (C.) Desain Interior sesuai zone fungsi ruang.

Sumber: Dokumen PT. Athila Consultant,2019 
b. Elemen Dinding

Material dinding yang digunakan terdiri dari 3 jenis, yaitu (1) dinding dengan bata merah diplester dan finishing cat; (2) dinding partisi kaca rangka alumunium; dan dinding partisi double gypsum finishing catan kombinasi wallpaper. Pemilihan warna untuk dinding bata merah dan partisi double gypsum menggunakan warna-warna netral yang dikombinasikan dengan warna kontrasnya pada bagian dinding tertentu yang tetap memberikan kesan luas dan bersih.
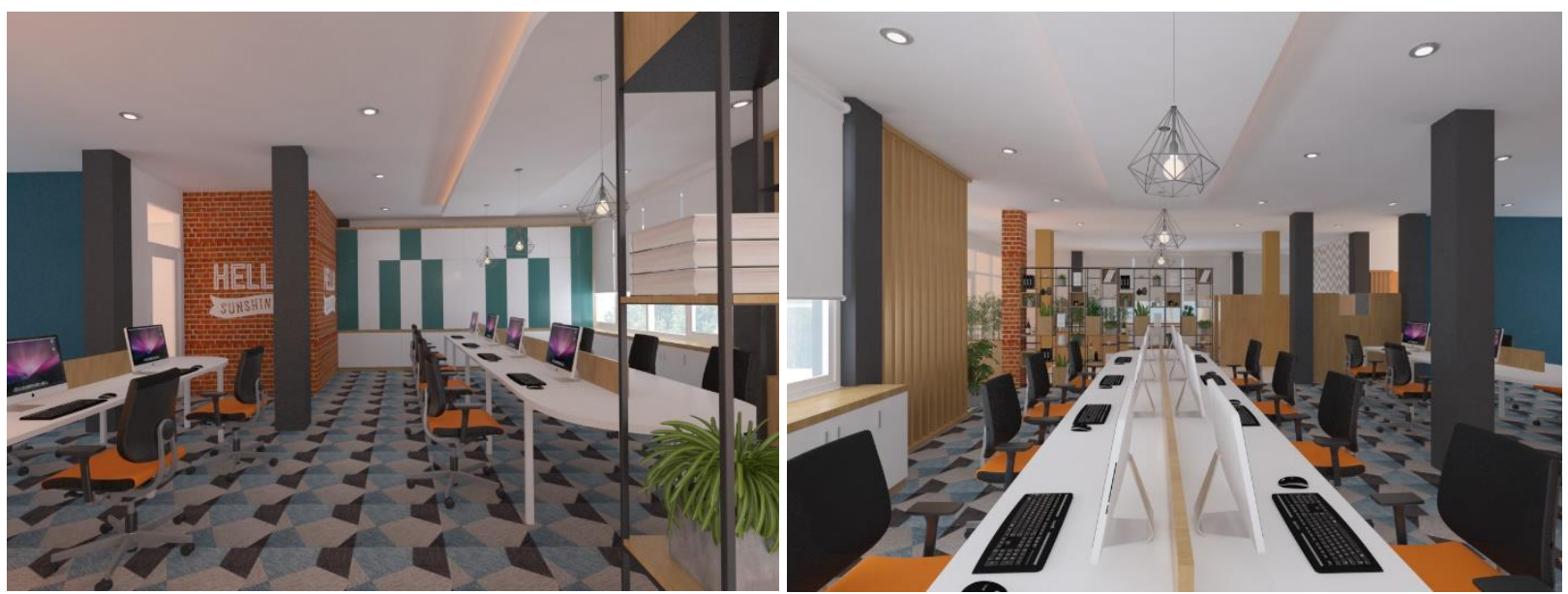

Gambar 12. (A.) Denah Existing; (B.) Pengelompokkan Zone sesuai fungsi ruang; dan (C.) Desain Interior sesuai pendaerahan/zone fungsi ruang.

Sumber: Desain peneliti, 2019

c. Elemen Plafond

Material plafond menggunakan gypsum finishing cat warna white apple sangat mencirikan kesan luas dengan ditunjang oleh elemen pencahayaan yang optimal dan maksimal.

d. Furnitur dan perabotan

Penerapan penggunaan furnitur dengan memadukan bentuk yang simpel modern dengan khas industrial hand made yang memiliki karakteristik yang unik dan sederhanafurniture dirancangan sederhana tetapi tetap mempertimbangkan aspek antropometri, ergonomi, dan nyaman serta fungsional.

e. Elemen Estetis

Penggunaan dekorasi sebagai elemen estetik yang dipilih dengan bentuk-bentuk yang simpel. Pada bagian sudut-sudut dinding tertentu dipasang bebesapa pigura yang diperkuat oleh lampu spot memberikan kesan maskulin.

f. Pencahayaan dan Penghawaan

Penggunaan cahaya buatan diminimalisir, sebab kantor dirancang dengan banyak bukaan. Cahaya alami dari sinar matahari dimanfaatkan secara optimal. Cahaya buatan menggunakan lampu jenis LED untuk menghemat energi sampai 60\% jika dibandingkan lampu biasa. Pada beberapa dinding tertentu digunakan lampu spot sebagai aksen yang mempercantik tampilan ruangan.

Konsep penghawaan menggunakan penghawaan buatan. Penggunaan penghawaan buatan adalah jenis AC sentra. Penggunaan AC sentral memberikan kesan secara menyeluruh dan seluruh pengguna merasa sejuk dan nyaman di dalam kantor.

Konsep perancangan interior untuk ruang kantor ini ditujukan untuk memberikan peningkatan kualitas lingkungan kerja dan kualitas kerja, memberikan panduan yang fungsional dan efisiensi dalam mewadahi keberagaman aktivitas, dan mendorong terjadinya interaksi dan kerja tim antar staf/pegawai, serta mendorong munculnya inovasi melalui proses kreatif. Berdasarkan tujuan ini maka untuk mendukung suasana ruang yang diinginkan diimplementasikan beberapa material dalam desain interio kantor ini.

Kelengkapan fasilitas pendukung seperti furniture dan perabotan, kapasitas besaran ruang yang dirancang telah memenuhi standar dan suseai dengan acuan data baik literatur maupun peraturan yang berlaku, sehingga kenyamanan dan keamanan beraktivitas semua pegawai terjamin. Selain itu penggunaan bahan material interior juga sudah memenuhi persyaratan dan standar. 


\subsection{Space Syntax Analysis}

Adanya keberagaman aktivitas membutuhkan satu konfigurasi ruang yang efektif dan efisien. Konfigurasi ini ditentukan oLeh pembentuk stuktur ruang. Dalam suatu konfigurasi pada dasarnya ruang tidak hanya berbentuk node tetapi juga sebagai path atau jalur yang umumnya bersifat publik(Siregar, 2014). Node dan path sebagai satu sistem dalam menghubungkan ruang satu dengan lainnya dalam satu sistem hubungan (linkage system). Di dalam re-desain suasana ruang interior PT. Haleyora Powerindo terdapat beberapa ruang yang menjadi ruang pengamatan yang diobservasi. Tujuannya untuk mencari tingkat konektivitas ruang yang digunakan untuk ruang kerja staf/pegawai. Berdasarkan analisis space syntax dengan bantuan software depthmapX v.0.70 dapat dilihat bagaimana nilai connectivity antar ruang di dalam satu lantai maupun berbeda lantai, seperti terlihat pada gambar 13 .
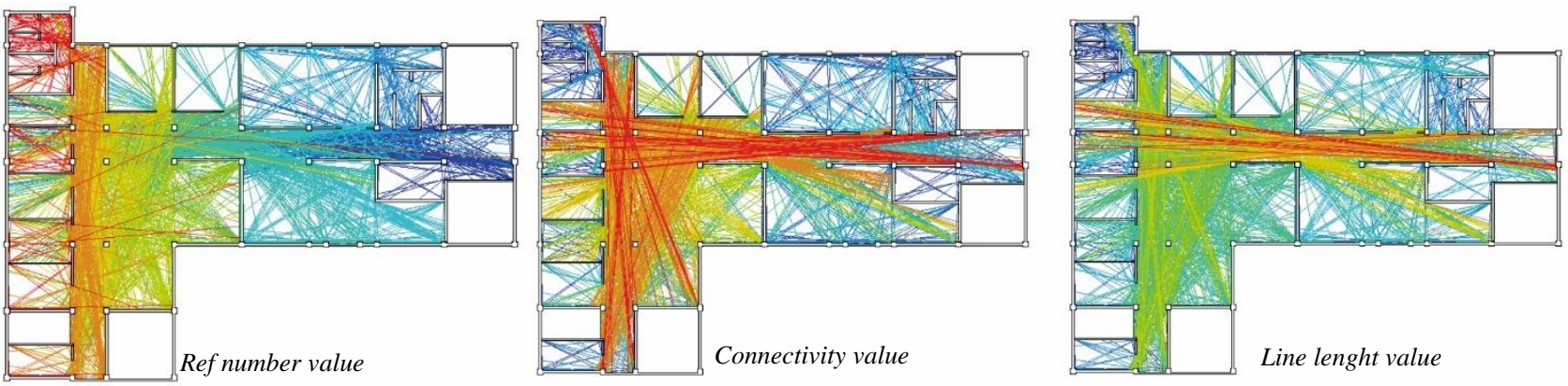

Gambar 13. Ilustrasi hasil Space Syntax Analysis (A). Ref number value; (B). Connectivity value; dan (C). Line length value untuk Denah Lantai Dasar Sumber: Data Penulis, 2019
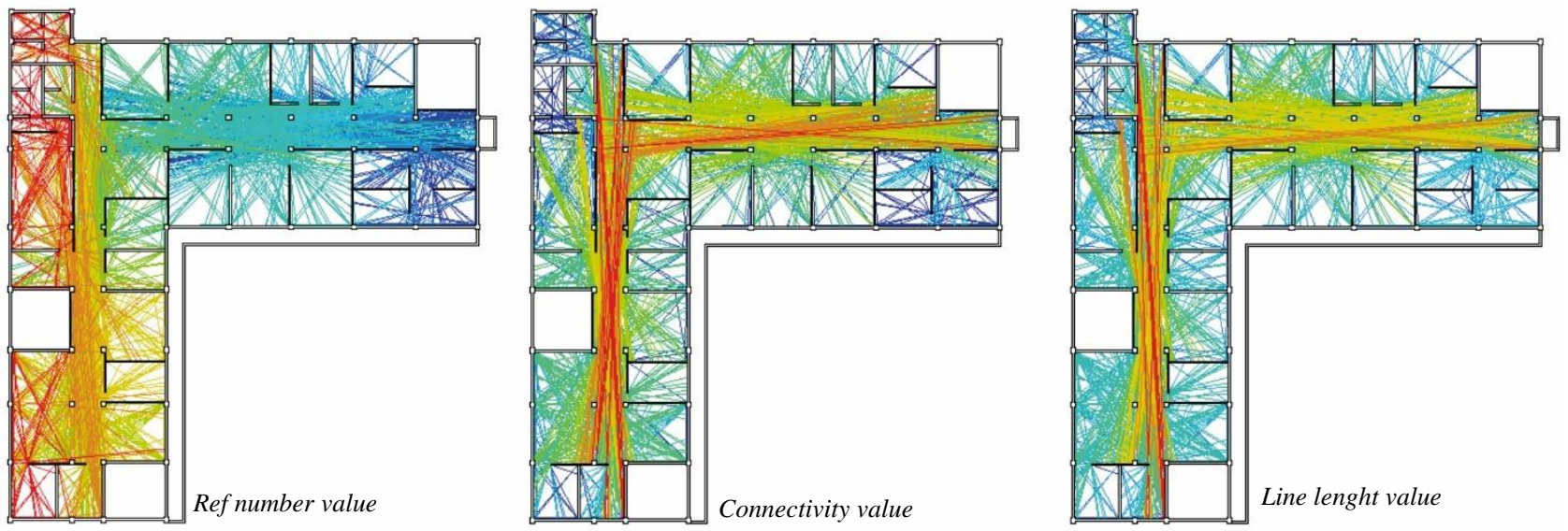

Gambar 14. Ilustrasi hasil Space Syntax Analysis (A). Ref number value; (B). Connectivity value; dan (C). Line length value untuk Denah Lantai Dua Sumber: Data Penulis, 2019
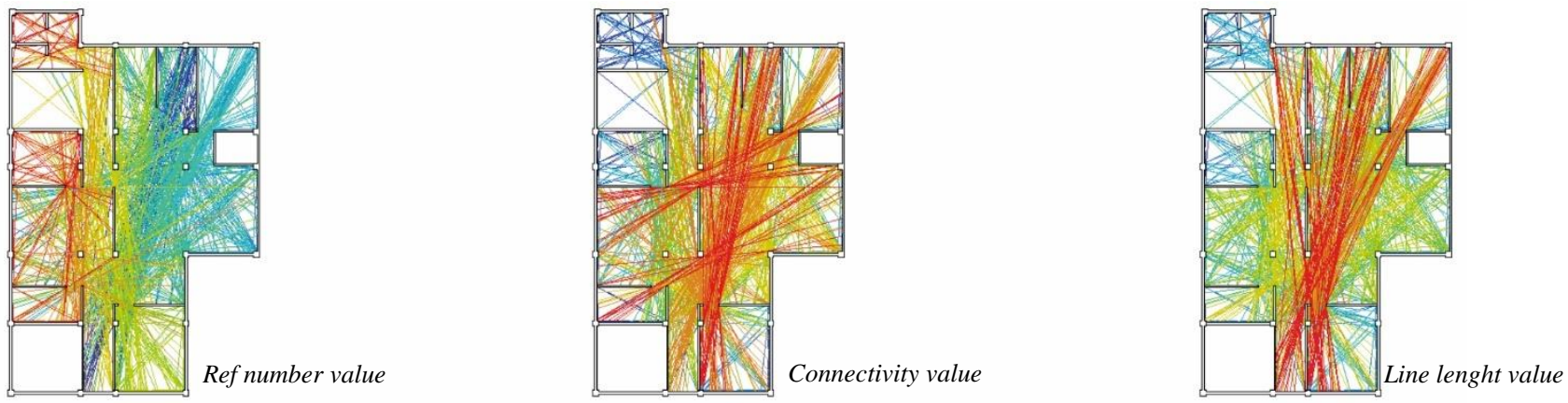

Gambar 15. Ilustrasi hasil Space Syntax Analysis (A). Ref number value; (B). Connectivity value; dan (C). Line length value untuk Denah Lantai Dua

Sumber: Data Penulis, 2019 


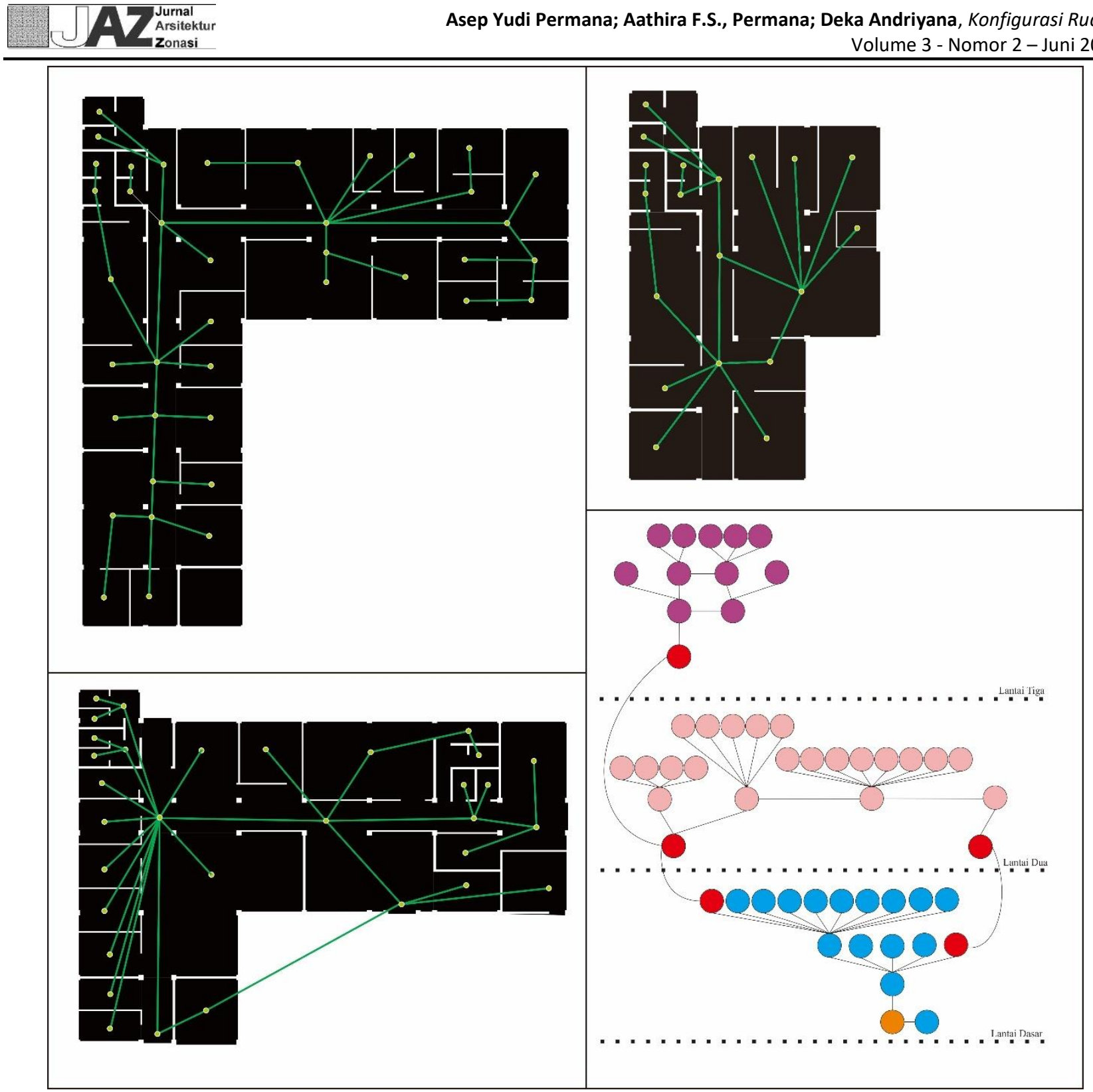

Gambar 16. (A,B,C) Analisis hubungan ruang berdasarkan konfigurasi solid void; (D) Diagram hubungan ruang dalam setiap lantai

Sumber: Data peneliti, 2019

Berdasarkan gambar ilustrasi dan hasil perhitungan konfigurasi ruang berdasarkan konsep integritas dalam metode space sintax analysis dapat dilihat pada tabel 1 berikut:

Tabel 1. Perhitungan TD, MD, dan RA Lantai Dasar

\begin{tabular}{|c|c|c|c|}
\hline Ruang & $\begin{array}{c}\text { Total } \\
\text { Depth } \\
\text { (TD) }\end{array}$ & $\begin{array}{c}\text { Mean } \\
\text { Depth } \\
\text { (MD) }\end{array}$ & $\begin{array}{c}\text { Relative } \\
\text { Asymmetry } \\
\text { (RA) }\end{array}$ \\
\hline A & 40 & 2,22 & 0.14 \\
\hline B & 55 & 3,06 & 0,24 \\
\hline C & 26 & 1,44 & 0,05 \\
\hline D & 39 & 2,17 & 0,14 \\
\hline E & 39 & 2,17 & 0,14 \\
\hline F & 39 & 2,17 & 0,14 \\
\hline G & 39 & 2,17 & 0,14 \\
\hline H & 21 & 1,17 & 0,02 \\
\hline I & 34 & 1,89 & 0,11 \\
\hline J & 34 & 1,89 & 0,11 \\
\hline
\end{tabular}

\begin{tabular}{|c|c|c|c|}
\hline Ruang & $\begin{array}{c}\text { Total } \\
\text { Depth } \\
\text { (TD) }\end{array}$ & $\begin{array}{c}\text { Mean } \\
\text { Depth } \\
\text { (MD) }\end{array}$ & $\begin{array}{c}\text { Relative } \\
\text { Asymmetry } \\
\text { (RA) }\end{array}$ \\
\hline K & 34 & 1,89 & 0,11 \\
\hline L & 34 & 1,89 & 0,11 \\
\hline M & 34 & 1,89 & 0,11 \\
\hline N & 34 & 1,89 & 0,11 \\
\hline O & 34 & 1,89 & 0,11 \\
\hline P & 34 & 1,89 & 0,11 \\
\hline Q & 34 & 1,89 & 0,11 \\
\hline R & 34 & 1,89 & 0,11 \\
\hline S & 55 & 3,06 & 0,24 \\
\hline
\end{tabular}

Sumber: Hasil Analisis peneliti, 2019 
Berdasarkan hasil data perhituangan total depth (TD), Mean depth (MD), dan Relative Asymmetry (RA), selanjutnya dilakukan perhitungan Real Relative Asymetry (RRA) yang digunakan untuk mendapatkan gambar nilai integritas secara operasional pada konfigurasi ruang. Adapun hasil perhitungan ini dapat dilihat pada tabel 2,3 , dan 4 .

Tabel 2. Perhitungan GL

\begin{tabular}{|c|c|c|c|c|c|c|c|}
\hline $\mathbf{L}$ & $\sqrt{ } \mathbf{L}$ & $\mathbf{2 L}$ & $\begin{array}{c}\mathbf{L} \sqrt{ }(\mathbf{L})- \\
\mathbf{2}+\mathbf{1}\end{array}$ & $\mathbf{L - 1}$ & $\mathbf{L - 2}$ & $\begin{array}{c}(\mathbf{L}-1) \\
(\mathbf{L}-2)\end{array}$ & GL \\
\hline 19 & 4,36 & 38 & 43,84 & 18 & 17 & 306 & 0,287 \\
\hline
\end{tabular}

Sumber: Analisis Peneliti, 2019

Tabel 3. Perhitungan RRA

\begin{tabular}{|c|c|}
\hline Ruang & RRA \\
\hline A & $\mathbf{0 , 4 8 8}$ \\
\hline B & $\mathbf{0 , 8 3 6}$ \\
\hline C & $\mathbf{0 , 1 7 4}$ \\
\hline D & $\mathbf{0 , 4 8 8}$ \\
\hline E & $\mathbf{0 , 4 8 8}$ \\
\hline F & $\mathbf{0 , 4 8 8}$ \\
\hline G & $\mathbf{0 , 4 8 8}$ \\
\hline H & $\mathbf{0 , 0 7 0}$ \\
\hline I & $\mathbf{0 , 3 8 3}$ \\
\hline J & $\mathbf{0 , 3 8 3}$ \\
\hline
\end{tabular}

\begin{tabular}{|c|c|}
\hline Ruang & RRA \\
\hline K & $\mathbf{0 , 3 8 3}$ \\
\hline L & $\mathbf{0 , 3 8 3}$ \\
\hline M & $\mathbf{0 , 3 8 3}$ \\
\hline $\mathbf{N}$ & $\mathbf{0 , 3 8 3}$ \\
\hline $\mathbf{O}$ & $\mathbf{0 , 3 8 3}$ \\
\hline P & $\mathbf{0 , 3 8 3}$ \\
\hline $\mathbf{Q}$ & $\mathbf{0 , 3 8 3}$ \\
\hline R & $\mathbf{0 , 3 8 3}$ \\
\hline S & $\mathbf{0 , 8 3 6}$ \\
\hline
\end{tabular}

Sumber: Analisis Peneliti, 2019

Tabel 4. Perhitungan TD, MD, dan RA Lantai Dua

\begin{tabular}{|c|c|c|c|}
\hline Ruang & $\begin{array}{c}\text { Total } \\
\text { Depth } \\
\text { (TD) }\end{array}$ & $\begin{array}{c}\text { Mean } \\
\text { Depth } \\
\text { (MD) }\end{array}$ & $\begin{array}{c}\text { Relative } \\
\text { Asymmetry } \\
\text { (RA) }\end{array}$ \\
\hline A & 57 & 2,478 & 0,134 \\
\hline B & 67 & 2,913 & 0,174 \\
\hline C & 47 & 2,043 & 0,095 \\
\hline D & 45 & 1,957 & 0,087 \\
\hline E & 72 & 3,130 & 0,194 \\
\hline F & 93 & 4,043 & 0,277 \\
\hline G & 93 & 4,043 & 0,277 \\
\hline H & 93 & 4,043 & 0,277 \\
\hline I & 93 & 4,043 & 0,277 \\
\hline J & 64 & 2,783 & 0,162 \\
\hline K & 64 & 2,783 & 0,162 \\
\hline L & 64 & 2,783 & 0,162 \\
\hline
\end{tabular}

\begin{tabular}{|c|c|c|c|}
\hline Ruang & $\begin{array}{c}\text { Total } \\
\text { Depth } \\
\text { (TD) }\end{array}$ & $\begin{array}{c}\text { Mean } \\
\text { Depth } \\
\text { (MD) }\end{array}$ & $\begin{array}{c}\text { Relative } \\
\text { Asymmetry } \\
\text { (RA) }\end{array}$ \\
\hline M & 64 & 2,783 & 0,162 \\
\hline N & 64 & 2,783 & 0,162 \\
\hline O & 64 & 2,783 & 0,162 \\
\hline P & 64 & 2,783 & 0,162 \\
\hline Q & 64 & 2,783 & 0,162 \\
\hline R & 52 & 2,261 & 0,115 \\
\hline S & 52 & 2,261 & 0,115 \\
\hline T & 52 & 2,261 & 0,115 \\
\hline U & 52 & 2,261 & 0,115 \\
\hline V & 52 & 2,261 & 0,115 \\
\hline W & 52 & 2,261 & 0,115 \\
\hline X & 52 & 2,261 & 0,115 \\
\hline
\end{tabular}

Sumber: Hasil Analisis peneliti, 2019

Berdasarkan hasil data perhituangan total depth (TD), Mean depth (MD), dan Relative Asymmetry (RA), selanjutnya dilakukan perhitungan Real Relative Asymetry (RRA) yang digunakan untuk mendapatkan gambar nilai integritas secara operasional pada konfigurasi ruang. Adapun hasil perhitungan ini dapat dilihat pada tabel 5,6 , dan 7 .

Tabel 5. Perhitungan GL

\begin{tabular}{|c|c|c|c|c|c|c|c|}
\hline $\mathbf{L}$ & $\sqrt{ } \mathbf{L}$ & $\mathbf{2 L}$ & $\begin{array}{c}\mathbf{L} \sqrt{ }(\mathbf{L})- \\
\mathbf{2}+\mathbf{1}\end{array}$ & $\mathbf{L}-\mathbf{1}$ & $\mathbf{L - 2}$ & $\begin{array}{c}(\mathbf{L}-1) \\
(\mathbf{L}-2)\end{array}$ & GL \\
\hline 24 & 4,899 & 48 & 68,576 & 23 & 22 & 506 & 0,271 \\
\hline
\end{tabular}

Sumber: Analisis Peneliti, 2019 
Tabel 6. Perhitungan RRA

\begin{tabular}{|c|c|}
\hline Ruang & RRA \\
\hline A & 0,495 \\
\hline B & 0,642 \\
\hline C & 0,350 \\
\hline D & 0,321 \\
\hline E & 1,022 \\
\hline F & 1,022 \\
\hline G & 1,022 \\
\hline H & 1,022 \\
\hline I & 1,022 \\
\hline J & 0,598 \\
\hline K & 0,598 \\
\hline L & 0,598 \\
\hline
\end{tabular}

\begin{tabular}{|c|c|}
\hline Ruang & RRA \\
\hline M & 0,598 \\
\hline N & 0,598 \\
\hline O & 0,598 \\
\hline P & 0,598 \\
\hline Q & 0,598 \\
\hline R & 0,424 \\
\hline S & 0,424 \\
\hline T & 0,424 \\
\hline U & 0,424 \\
\hline W & 0,424 \\
\hline X & 0,424 \\
\hline
\end{tabular}

Tabel 7. Perhitungan TD, MD, dan RA Lantai Tiga

\begin{tabular}{|c|c|c|c|}
\hline Ruang & $\begin{array}{c}\text { Total } \\
\text { Depth } \\
\text { (TD) }\end{array}$ & $\begin{array}{c}\text { Mean } \\
\text { Depth } \\
\text { (MD) }\end{array}$ & $\begin{array}{c}\text { Relative } \\
\text { Asymmetry } \\
\text { (RA) }\end{array}$ \\
\hline A & 63 & 5,726 & 1,890 \\
\hline B & 41 & 3,727 & 0,545 \\
\hline C & 45 & 4,091 & 0,618 \\
\hline D & 49 & 4,454 & 0,691 \\
\hline E & 39 & 3,546 & 0,509 \\
\hline F & 31 & 2,818 & 0,364 \\
\hline G & 53 & 4,818 & 0,764 \\
\hline H & 55 & 5,000 & 1,000 \\
\hline I & 55 & 5,000 & 1,000 \\
\hline J & 55 & 5,000 & 1,000 \\
\hline K & 61 & 5,546 & 1,092 \\
\hline L & 61 & 5,546 & 1,092 \\
\hline
\end{tabular}

Sumber: Hasil Analisis peneliti, 2019

Berdasarkan hasil data perhituangan total depth (TD), Mean depth (MD), dan Relative Asymmetry (RA), selanjutnya dilakukan perhitungan Real Relative Asymetry (RRA) yang digunakan untuk mendapatkan gambar nilai integritas secara operasional pada konfigurasi ruang. Adapun hasil perhitungan ini dapat dilihat pada tabel 8 dan 9.

Tabel 8. Perhitungan GL

\begin{tabular}{|c|c|c|c|c|c|c|c|}
\hline $\mathbf{L}$ & $\sqrt{ } \mathbf{L}$ & $\mathbf{2 L}$ & $\begin{array}{c}\mathbf{L} \sqrt{ }(\mathbf{L})- \\
\mathbf{2} \mathbf{+}+1\end{array}$ & $\mathbf{L - 1}$ & $\mathbf{L - 2}$ & $\begin{array}{c}(\mathbf{L}-1) \\
(\mathbf{L}-2)\end{array}$ & GL \\
\hline 12 & 3,464 & 24 & 16,568 & 11 & 10 & 110 & 0,301 \\
\hline
\end{tabular}

Tabel 9. Perhitungan RRA

Sumber: Analisis Peneliti, 2019

\begin{tabular}{|c|r|}
\hline RUANG & RRA \\
\hline A & 6,279 \\
\hline B & 1,811 \\
\hline C & 2,053 \\
\hline D & 2,296 \\
\hline E & 1,691 \\
\hline F & 1,209 \\
\hline
\end{tabular}

\begin{tabular}{|c|r|}
\hline RUANG & RRA \\
\hline G & 2,538 \\
\hline H & 3,322 \\
\hline I & 3,322 \\
\hline J & 3,322 \\
\hline K & 3,628 \\
\hline L & 3,628 \\
\hline
\end{tabular}

Sumber: Analisis Peneliti, 2019

Berdasarkan hasil analisis, ruang pada Lantai Dasar, Lantai Dua, dan Lantai Tiga ruang kerja staf/ pegawai memiliki nilai integritas yang lebih tinggi dibandingkan dengan ruang lainnya. Ruang kerja Staf memiliki nilai integritas yang lebih tinggi artinya ruang ini memiliki kesatuan yang paling erat terhadap konfigurasi ruang secara keseluruhan dibandingkan ruang-ruang lain. Dengan demikian berdasarkan konsep 
topological distance, ruang kerja staf (Siregar, 2014)adalah ruang yang paling mudah untuk dijangkau dari seluruh ruang lainnya dalam konfigurasi ruang tersebut karena memiliki ruang antara yang lebih sedikit, sedangkan bila dikaitkan dengan teori natural movement, ruang kerja staf adalah ruang yang dapat dihipotesiskan sebagai ruang yang paling banyak ditemukan aktivitas pergerakan penggunanya(Siregar, 2014). Hasil perhitungan nilai intelligibility untuk konfigurasi ruang pada kantor PT. Haleyora Powerindo adalah:

a. Perhitungan r product moment untuk konfigurasi ruang di Lantai Dasar, (data pada tabel 10)

Tabel 10. Perhitungan $r$ product moment

\begin{tabular}{|c|c|c|c|c|c|c|c|}
\hline Ruang & $\mathbf{R A}$ & RRA & $\mathbf{x}$ & $\mathbf{y}$ & $x^{2}$ & $\mathbf{y}^{2}$ & $\mathbf{x y}$ \\
\hline A & 0.14 & 0.488 & 0.02 & 0.06 & 0.0003 & 0.0033 & 0.0009 \\
\hline $\mathrm{B}$ & 0.24 & 0.836 & 0.12 & 0.41 & 0.0135 & 0.1642 & 0.0471 \\
\hline $\mathrm{C}$ & 0.05 & 0.174 & -0.07 & -0.26 & 0.0054 & 0.0660 & 0.0189 \\
\hline $\mathrm{D}$ & 0.14 & 0.488 & 0.02 & 0.06 & 0.0003 & 0.0033 & 0.0009 \\
\hline$E$ & 0.14 & 0.488 & 0.02 & 0.06 & 0.0003 & 0.0033 & 0.0009 \\
\hline$F$ & 0.14 & 0.488 & 0.02 & 0.06 & 0.0003 & 0.0033 & 0.0009 \\
\hline $\mathrm{G}$ & 0.14 & 0.488 & 0.02 & 0.06 & 0.0003 & 0.0033 & 0.0009 \\
\hline $\mathrm{H}$ & 0.02 & 0.07 & -0.10 & -0.36 & 0.0108 & 0.1302 & 0.0374 \\
\hline I & 0.11 & 0.383 & -0.01 & -0.05 & 0.0002 & 0.0023 & 0.0007 \\
\hline $\mathbf{J}$ & 0.11 & 0.383 & -0.01 & -0.05 & 0.0002 & 0.0023 & 0.0007 \\
\hline $\mathrm{K}$ & 0.11 & 0.383 & -0.01 & -0.05 & 0.0002 & 0.0023 & 0.0007 \\
\hline $\mathbf{L}$ & 0.11 & 0.383 & -0.01 & -0.05 & 0.0002 & 0.0023 & 0.0007 \\
\hline $\mathbf{M}$ & 0.11 & 0.383 & -0.01 & -0.05 & 0.0002 & 0.0023 & 0.0007 \\
\hline $\mathrm{N}$ & 0.11 & 0.383 & -0.01 & -0.05 & 0.0002 & 0.0023 & 0.0007 \\
\hline $\mathrm{O}$ & 0.11 & 0.383 & -0.01 & -0.05 & 0.0002 & 0.0023 & 0.0007 \\
\hline $\mathrm{P}$ & 0.11 & 0.383 & -0.01 & -0.05 & 0.0002 & 0.0023 & 0.0007 \\
\hline$Q$ & 0.11 & 0.383 & -0.01 & -0.05 & 0.0002 & 0.0023 & 0.0007 \\
\hline $\mathrm{R}$ & 0.11 & 0.383 & -0.01 & -0.05 & 0.0002 & 0.0023 & 0.0007 \\
\hline $\mathrm{S}$ & 0.24 & 0.836 & 0.12 & 0.41 & 0.0135 & 0.1642 & 0.0471 \\
\hline \begin{tabular}{|l|} 
JUMLAH \\
\end{tabular} & 2.35 & 8.186 & 0.00 & 0.00 & 0.0464 & 0.5637 & 0.1618 \\
\hline \multirow[t]{3}{*}{ Rata-rata } & \multirow[t]{3}{*}{0.12} & \multirow[t]{3}{*}{0.431} & & \multirow{3}{*}{\multicolumn{2}{|c|}{\begin{tabular}{|l|l|}
$\mathbf{x}^{2} \mathbf{y}^{2}$ \\
SQRT \\
$\mathbf{r}_{\mathrm{xy}}$ \\
\end{tabular}}} & 0.0262 & \\
\hline & & & & & & 0.1618 & \\
\hline & & & & & & 1.000 & \\
\hline
\end{tabular}

Sumber: Data peneliti, 2019

Berdasarkan hasil perhitungan didapat nilai $r$ product moment $r_{x y}=1,00$ dengan $n=19$ pada tingkat kepercayaan $95 \%$, maka $r$ tabel $=0,456$. Dengan demikian maka $r_{\text {hitung }}>r_{\text {tabel }}$, maka terdapat korelasi yang signifikan antara RA dan RRA.

b. Perhitungan $r$ product moment untuk konfigurasi ruang di Lantai Dua (data pada tabel 11)

Tabel 11. Perhitungan $\mathrm{r}$ product moment

\begin{tabular}{|c|c|c|c|c|c|c|c|}
\hline Ruang & $\mathbf{R A}$ & RRA & $\mathbf{x}$ & $\mathbf{y}$ & $x^{2}$ & $\mathbf{y}^{2}$ & $\mathbf{x y}$ \\
\hline A & 0.134 & 0.495 & -0.06 & $(0.28)$ & 0.0042 & 0.0768 & 0.0180 \\
\hline B & 0.174 & 0.642 & -0.02 & -0.13 & 0.0006 & 0.0169 & 0.0032 \\
\hline $\mathrm{C}$ & 0.095 & 0.35 & -0.10 & -0.42 & 0.0108 & 0.1782 & 0.0438 \\
\hline $\mathrm{D}$ & 0.087 & 0.321 & -0.11 & -0.45 & 0.0125 & 0.2035 & 0.0505 \\
\hline $\mathrm{E}$ & 0.194 & 1.022 & 0.00 & 0.25 & 0.0000 & 0.0624 & $(0.0012)$ \\
\hline$F$ & 0.277 & 1.022 & 0.08 & 0.25 & 0.0061 & 0.0624 & 0.0195 \\
\hline $\mathrm{G}$ & 0.277 & 1.022 & 0.08 & 0.25 & 0.0061 & 0.0624 & 0.0195 \\
\hline $\mathrm{H}$ & 0.277 & 1.022 & 0.08 & 0.25 & 0.0061 & 0.0624 & 0.0195 \\
\hline I & 0.162 & 1.022 & -0.04 & 0.25 & 0.0014 & 0.0624 & $(0.0092)$ \\
\hline $\mathbf{J}$ & 0.162 & 0.598 & -0.04 & -0.17 & 0.0014 & 0.0303 & 0.0064 \\
\hline $\mathrm{K}$ & 0.162 & 0.598 & -0.04 & -0.17 & 0.0014 & 0.0303 & 0.0064 \\
\hline $\mathrm{L}$ & 0.162 & 0.598 & -0.04 & -0.17 & 0.0014 & 0.0303 & 0.0064 \\
\hline $\mathbf{M}$ & 0.162 & 0.598 & -0.04 & -0.17 & 0.0014 & 0.0303 & 0.0064 \\
\hline $\mathrm{N}$ & 0.162 & 0.598 & -0.04 & -0.17 & 0.0014 & 0.0303 & 0.0064 \\
\hline $\mathrm{O}$ & 0.162 & 0.598 & -0.04 & -0.17 & 0.0014 & 0.0303 & 0.0064 \\
\hline $\mathrm{P}$ & 0.162 & 0.598 & -0.04 & -0.17 & 0.0014 & 0.0303 & 0.0064 \\
\hline$Q$ & 0.162 & 0.598 & -0.04 & -0.17 & 0.0014 & 0.0303 & 0.0064 \\
\hline $\mathrm{R}$ & 0.115 & 0.424 & -0.08 & -0.35 & 0.0070 & 0.1212 & 0.0292 \\
\hline $\mathrm{S}$ & 0.115 & 0.424 & -0.08 & -0.35 & 0.0070 & 0.1212 & 0.0292 \\
\hline $\mathrm{T}$ & 0.115 & 0.424 & -0.08 & -0.35 & 0.0070 & 0.1212 & 0.0292 \\
\hline $\mathrm{U}$ & 0.115 & 0.424 & -0.08 & -0.35 & 0.0070 & 0.1212 & 0.0292 \\
\hline $\mathrm{V}$ & 0.115 & 0.424 & -0.08 & -0.35 & 0.0070 & 0.1212 & 0.0292 \\
\hline $\mathrm{W}$ & 0.115 & 0.424 & -0.08 & -0.35 & 0.0070 & 0.1212 & 0.0292 \\
\hline$X$ & 0.115 & 0.424 & -0.08 & -0.35 & 0.0070 & 0.1212 & 0.0292 \\
\hline JUMLAH & 3.778 & 14.67 & -0.99 & $(3.86)$ & 0.1079 & 1.8784 & 0.4193 \\
\hline Rata-rata & 0.20 & 0.772 & & & $x^{2} y^{2}$ & 0.2026 & \\
\hline \multirow{2}{*}{ 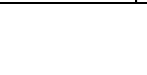 } & & & & & SQRT & 0.4502 & \\
\hline & & & & & $\mathbf{r}_{\mathbf{x y}}$ & 0.931 & \\
\hline
\end{tabular}

Sumber: Data peneliti, 2019 
Berdasarkan hasil perhitungan nilai $r$ product moment $r_{x y}=0,931$ dengan $n=24$ pada tingkat kepercayaan $95 \%$, maka $r$ tabel $=0,404$. Dengan demikian maka $r_{\text {hitung }}>r_{\text {tabel }}$, maka terdapat korelasi yang signifikan antara RA dan RRA.

c. Perhitungan $\mathrm{r}$ product moment untuk konfigurasi ruang di Lantai Tiga (data pada tabel 12)

Tabel 12. Perhitungan $\mathrm{r}$ product moment

\begin{tabular}{|c|c|c|c|c|c|c|c|}
\hline Ruang & $\mathbf{R A}$ & RRA & $\mathbf{x}$ & $\mathbf{y}$ & $x^{2}$ & $\mathbf{y}^{2}$ & $\mathbf{x y}$ \\
\hline A & 1.890 & 6.279 & 1.33 & 4.43 & 1.7794 & 19.6398 & 5.9116 \\
\hline B & 0.545 & 1.811 & -0.01 & -0.04 & 0.0001 & 0.0013 & 0.0004 \\
\hline $\mathrm{C}$ & 0.618 & 2.053 & 0.06 & 0.21 & 0.0038 & 0.0423 & 0.0127 \\
\hline $\mathrm{D}$ & 0.691 & 2.296 & 0.13 & 0.45 & 0.0182 & 0.2013 & 0.0605 \\
\hline $\mathrm{E}$ & 0.509 & 1.691 & -0.05 & -0.16 & 0.0022 & 0.0244 & 0.0074 \\
\hline $\mathrm{F}$ & 0.364 & 1.209 & -0.19 & -0.64 & 0.0369 & 0.4074 & 0.1226 \\
\hline $\mathrm{G}$ & 0.764 & 2.538 & 0.21 & 0.69 & 0.0432 & 0.4770 & 0.1436 \\
\hline $\mathrm{H}$ & 1.000 & 3.322 & 0.44 & 1.47 & 0.1971 & 2.1747 & 0.6547 \\
\hline I & 1.000 & 3.322 & 0.44 & 1.47 & 0.1971 & 2.1747 & 0.6547 \\
\hline $\mathbf{J}$ & 1.000 & 3.322 & 0.44 & 1.47 & 0.1971 & 2.1747 & 0.6547 \\
\hline $\mathrm{K}$ & 1.092 & 3.628 & 0.54 & 1.78 & 0.2872 & 3.1708 & 0.9544 \\
\hline $\mathrm{L}$ & 1.092 & 3.628 & 0.54 & 1.78 & 0.2872 & 3.1708 & 0.9544 \\
\hline JUMLAH & 10.565 & 35.099 & 3.89 & 12.93 & 3.0497 & 33.6594 & 10.1316 \\
\hline \multirow[t]{3}{*}{ Rata-rata } & \multirow[t]{3}{*}{0.56} & \multirow[t]{3}{*}{1.847} & & \multirow{3}{*}{\multicolumn{2}{|c|}{\begin{tabular}{|l|}
$\mathbf{x}^{2} \mathbf{y}^{2}$ \\
SQRT \\
\end{tabular}}} & 102.6503 & \\
\hline & & & & & & 10.1316 & \\
\hline & & & & & & 1.000 & \\
\hline
\end{tabular}

Sumber: Data peneliti, 2019

Berdasarkan hasil perhitungan nilai $r$ product moment $r_{x y}=1,000$ dengan $n=12$ pada tingkat kepercayaan $95 \%$, maka $r$ tabel $=0,576$. Dengan demikian maka $r_{\text {hitung }}>r_{\text {tabel }}$, maka terdapat korelasi yang signifikan antara RA dan RRA.

Secara keseluruhan berdasarkan hasil perhitungan intelligibility baik pad konfigurasi ruang di Lantai Dasar, Lantai Dua, dan Lantai Tiga ditemukan bahwa terdapat korelasi antara connectivity dengan integrity. Dengan demikian konfigurasi ruang mendukung pada kondisi di mana pengguna ruang dapat dengan mudah memahami bagaimana pola ruang yang ada terkait dengan daya jangkau dan sirkulasi utama pada konfigurasi ruang yang ada di kantor PT. Haleyora Powerindo.

\section{Kesimpulan}

Sesuai dengan tujuan dari re-desain suasana ruang interior yang dilakukan oleh PT. Haleyora Powerindo, di mana tujuan utama dalam penataan kembali suasana ruang yang ditujukan untuk memberikan rasa keterbukaan, adanya interaksi antar pegawai, dan ruang yang fleksibel. Hal ini tercapai melalui pengelompokan ruang berdasarkan pendaerahan dan fungsi ruang. Ruang kerja staf/pegawai ditempatkan di antara ruang-ruang manajer dengan konsep open space memberikan keleluasaan pegawai untuk berinteraksi satu dengan lainnya.

Konsep pengelompokkan ruang ini didukung dengan hasil dari penelitian melalui space syntax analysis di mana konfigurasi ruang berdasarkan hasil dari re-desain memberikan korelasi yang baik antara connectivity dan integrity. Dengan demikian konfigurasi ruang yang ada memberikan kemudahan seluruh pegawai utuk menjangka ke ruang lain sesuai butuhannya.

\section{Referensi}

Adien, J. M. V., dan Setiadi, A. (2017). Office Spatial Pattern Study in PG / PS Madukismo, Yogyakarta Using LEAN SIX SIGMA Approach. Proseding SCAN\#8: Education Putting "Eco-DNA" in Our Kids, 195205. Yogyakarta: Program Studi Arsitektur Fakultas Teknik Universitas Atma Jaya.

Adiyanto, J. (2016). Kajian Perubahan Ruang Terbuka pada Kawasan Bersejarah dengan Metode Space Syntax (Studi kasus Kawasan Kampung Kapitan Palembang). Jurnal Perencanaan Wilayah Dan Kota, 27(2), 103. https://doi.org/10.5614/jrcp.2016.27.2.3

Armiati. (2015). Meningkatkan Efektivitas Kerja Pegawai Melalui Penataan Layout Kantor. SEMINAR NASIONAL EKONOMI MANAJEMEN DAN AKUNTANSI (SNEMA) FAKULTAS EKONOMI UNIVERSITAS NEGERI PADANG, $\quad$ (c). $\quad$ Retrieved from http://fe.unp.ac.id/sites/default/files/unggahan/25. Armiati \%28hal 334-343\%29_0.pdf

Darjosanjoto, E. T. S. (2006). Penelitian Arsitektur di Bidang Perumahan dan Permukiman. Surabaya: ITS Press. 
Gie, T. L. (2000). Modern Office Administration. Yogyakarta: Liberty.

Hadiansyah, M. N. (2017). Kajian Faktor-Faktor yang Mempengaruhi Aksesibilitas dalam Ruang Pelayanan Publik Studi Kasus: BPJS Kesehatan Cabang Utama Bandung. Jurnal Desain Interior, 2(1), 27. https://doi.org/10.12962/j12345678.v2i1.2377

Hanson, J. (1998). Decoding Homes and Houses. https://doi.org/10.1017/CBO9780511518294

Hillier, B. (2007). Space is the machine: A Configuration Theory of Architecture. In Design Studies (Vol. 18). https://doi.org/10.1016/S0142-694X(97)89854-7

Hillier, B., Burdett, R., Peponis, J., dan Penn, A. (1987). Creating Life: Or, Does Architecture Determine Anything? (pp. 233-250). pp. 233-250. London WCIH OQB, Great Britain: Bartlett School of Architecture and Planning University College London.

Hillier, B., dan Hanson, J. (1984). The social logic of space. In Cambridge University Press (Vol. 13). https://doi.org/10.1016/0169-2046(86)90038-1

Hillier, B., Penn, A., Hanson, J., Grajewski, T., dan Xu, J. (1993). Natural Movement: or, Configuration and Attraction in Urban Pedestrian Movement. Environment and Planning B: Planning and Design, 20, 2966.

Hutama, I. A. W. (2016). Exploring the Sense of Place of an Urban. University of Twente, The Netherlands.

Littlefield, C. L., dan Peterson, R. L. (1956). Modern Office Management. Jersey: Prentice-Hall. Inc.

McLane, Y., \& Pable, J. (2020). Architectural Design Characteristics, Uses, and Perceptions of Community Spaces in Permanent Supportive Housing. Journal of Interior Design, 45(1), 33-52. https://doi.org/10.1111/joid.12165

Permana, A. Y., Akbardin, J., Farah, A., Permana, S., dan Nurrahman, H. (2020). The Concept Of Optimal Workplace In Providing A Great Experience To Improve Work Professionalism In The Interior Design Of Pln Corporate. International Journal of Advanced Science and Technology, 29(7), 3238-3254.

Permana, A. Y., Soetomo, S., Hardiman, G., dan Buchori, I. (2013). Smart Architecture as a Concept of Sustainable Development in the Improvement of the Slum Settlement area in Bandung. Internasional Refereed Journal of Engineering and Science, 2(9), 26-35.

Permana, A. Y., dan Wijaya, K. (2019). Analisis Konfigurasi Ruang Pondokan Mahasiswa Di Kawasan Taman Hewan Balubur - Tamansari, Bandung. Jurnal Arsitektur ARCADE, 3(1), 45. https://doi.org/10.31848/arcade.v3i1.209

Ridwan, R. M., Niswaty, R., dan Darwis, M. (2018). PENGARUH TATA RUANG KANTOR TERHADAP KINERJA PEGAWAINEGERI SIPIL PADA KANTOR BADAN PUSAT STATISTIK PROVINSI SULAWESI SELATAN. Retrieved from http://eprints.unm.ac.id/11139/1/JURNAL RIFKA MUSFIRA RIDWAN.pdf

Siregar, J. P. (2014). Metodologi dasar space syntax dalam analisis konfigurasi ruang. Retrieved from https://docobook.com/metodologi-dasar-space-syntax-dalam-analisis-konfigurasi-rua.html?cv=1

Warada, W., dan Mutiara, D. (2013). Analisis Space Syntax Rumah Susun Berbasis Gang Kampung. Simposium Nasional RAPI XII, A59-63. Solo: FT UMS.

Williamson, V. (2015). Creating an ideal workplace culture : the keys to unlocking people talent Creating An Ideal Workplace Culture : The Keys to Unlocking People Talent. ALSR 2010: Conference towards Future Possibilities, (February). Retrieved from https://www.researchgate.net/publication/41185570_ Creating_an_ideal_workplace_culture_the_keys_to_unlocking_people_talent 